\title{
DEVELOPMENT AND VALIDATION OF REVERSE PHASE-HIGH PERFORMANCE LIQUID CHROMATOGRAPHY ASSAY METHOD FOR ESTIMATION OF FENOFIBRATE IN TABLET DOSAGE FORM PREPARED USING CRYSTALLO-CO-AGGLOMERATES OF THE DRUG
}

\author{
SANTOSH GANDHI ${ }^{1 *}$, MANGESH BHALEKAR ${ }^{1}$ AND RAVINA MUTHA ${ }^{2}$ \\ ${ }^{1}$ Department of Pharmaceutical Chemistry, AISSMS College of Pharmacy, \\ Maharashtra, India \\ ${ }^{2}$ Department of Quality Assurance, AISSMS College of Pharmacy, Maharashtra, India
}

Published online: 24 May 2021

To cite this article: SANTOSH GANDHI, MANGESH BHALEKAR \& RAVINA MUTHA (2021) Development and validation of reverse phase-high performance liquid chromatography assay method for estimation of fenofibrate in tablet dosage form prepared using crystalloco-agglomerates of the drug, Malaysian Journal of Pharmaceutical Sciences, 19(1): 19-28, https://doi.org/10.21315/mjps2021.19.1.2

To link to this article: https://doi.org/10.21315/mjps2021.19.1.2

\begin{abstract}
The aim of the present study was to develop a simple isocratic reverse phase-high performance liquid chromatography (RP-HPLC) method and validate for the determination of fenofibrate in tablet dosage forms. RP-HPLC method was developed using Hi Q Sil $C_{18}(250 \mathrm{~cm} \times 4.6 \mathrm{~mm}, 5 \mu \mathrm{m})$ and mobile phase comprising $1 \mathrm{mM}$ ammonium acetate buffer: Acetonitrile $(10: 90 \mathrm{v} / \mathrm{v})$ at a flow rate of $1.0 \mathrm{~mL} / \mathrm{min}$. The detection was carried out at $290 \mathrm{~nm}$. The retention time was found to be $6.15 \pm 0.03$ min. Validation of the method was performed for precision, accuracy, linearity, robustness, specificity and sensitivity to conform to the International Conference on Harmonization (ICH) guidelines. The data of linear regression analysis indicated a good linear response in the concentration range of $5 \mu \mathrm{g} / \mathrm{mL}-30 \mu \mathrm{g} / \mathrm{mL}$ with correlation co-efficient $\left(R^{2}\right)$ of 0.997 . The developed method was found to be simple, sensitive, accurate and repeatable for assay of tablets of fenofibrate prepared using crystallo-co-agglomerates of the drug.
\end{abstract}

Keywords: Fenofibrate, Isocratic HPLC, RP-HPLC, Validation

\section{INTRODUCTION}

Fenofibrate, 1-methylethyl 2-[4-(4-chlorobenzoyl) phenoxy]-2-methylpropanoate, is used as antihyperlipidemic drug. Fenofibrate activates lipoprotein lipase, which reduces triglycerides and increases high density lipoprotein cholesterol. It exerts a variable but generally modest low density lipoprotein cholesterol-lowering effect (Gupta et al. 2010) (Figure 1).

"Corresponding author: santoshvgandhi@rediffmail.com

(C) Penerbit Universiti Sains Malaysia, 2021. This work is licensed under the terms of the Creative Commons Attribution (CC BY) (http://creativecommons.org/licenses/by/4.0/). 
<smiles>CC(C)OC(=O)C(C)(C)Oc1ccc(C(=O)c2ccc(Cl)cc2)cc1</smiles>

Figure 1: Structure of fenofibrate.

Literature survey revealed that, high performance liquid chromatography (HPLC) (Sahoo, Sahu and Patro 2014), stability indicating HPLC method (Rao et al. 2013), UV spectrophotometric (Salama et al. 2011) has been reported for fenofibrate estimation alone in pharmaceutical formulation. Also HPLC method has been reported for determination of fenofibrate in human serum (Manish Kumar et al. 2011; Zaman et al. 2009). Few HPLC methods are published for simultaneous estimation of fenofibrate along with atorvastatin (Deepan et al. 2011), rosuvastatin (Thriveni et al. 2013; Suresh Kumar and Rajendra Prasad 2010) and ezetimibe (Choudhari and Nikalje 2010). The present study describes the development and validation of a simple, specific, accurate and precise RP-HPLC method for determination of fenofibrate in tablet dosage forms, validated according to the International Conference on Harmonization (ICH) guidelines (ICH 2005).

\section{METHODS}

\section{Reagents and Chemicals}

Fenofibrate was a kind gift from Lupin Ltd. Polyethylene glycol (PEG 6000), was purchased from Loba Chemie (Mumbai, India). Acetonitrile (HPLC grade) and dichloromethane (DCM) were purchased from Merck Specialities Ltd. HPLC grade water was collected at college using ELGA water purification system. Talc, sodium lauryl sulphate (SLS), starch, PVP K-30, lactose used were purchased from Loba Chemie (Mumbai, India).

\section{Preparation of Optimised Crystallo-Co-Agglomerates (Kadam, Mahadik and Paradkar 1997)}

In a crystallisation vessel, fenofibrate was dissolved in required amount of acetone (good solvent) to make saturated solution. This was added to aqueous solution of PEG 6000 (bad solvent), with stirring using a mechanical stirrer (Remi Motors, Mumbai) for 15 min, following which dichloromethane (DCM) was added slowly which acted as bridging liquid. The temperature of the crystallisation system was maintained below $5^{\circ} \mathrm{C}$ using sodium chloride ice mixture. The stirring was continued to obtain agglomerates, which were then filtered and dried overnight at room temperature.

Preparation of Tablets of Optimised Crystallo-Co-Agglomerates (Patil et al. 2011; Dongare, Bhalekar and Gandhi 2017)

All the materials are shown in the formula (Table 1). The material was then mixed by geometric mixing technique. Mixing was continued for about $30 \mathrm{~min}$ until a homogenous powder blend was obtained. Lactose was used as diluent, PVP K-30 was used as dry

Malay J Pharm Sci, Vol. 19, No. 1 (2021): 19-28 
binder, SLS was used as dispersing agent, talc was used as lubricant and starch as disintegrant. Tablets were prepared by direct compression method using standard $10.5 \mathrm{~mm}$ concave punches on rotary tablet compression machine (Rimek Mini Press II MT). All the product and process variables like mixing time and hardness, were kept constant and within permissible limits.

Table 1: Formulae for preparation of tablets.

\begin{tabular}{clc}
\hline No. & Ingredient & Amount $(\mathbf{m g})$ \\
\hline 1 & Fenofibrate crytalllo-co-agglomerates & 80 \\
2 & Starch & 4.5 \\
3 & SLS & 3 \\
4 & PVP K-30 & 12 \\
5 & Talc & 3 \\
6 & Lactose & Quantum satis (QS) \\
\hline
\end{tabular}

Note: "Total weight of the tablets was kept $150 \mathrm{mg}$.

\section{Selection of Mobile Phase and Chromatographic Conditions}

Chromatographic separation studies were carried out on the working standard solution of fenofibrate $10 \mu \mathrm{g} / \mathrm{mL}$. Initially, trials were carried out using methanol and acetonitrile in various proportions along with buffer of varying $\mathrm{pH}$, to obtain the desired system suitability parameters. Reverse phase (RP)-HPLC method was developed on Jasco HPLC system equipped with UV/VIS detector using Hi Q Sil C18 $(250 \mathrm{~cm} \times 4.6 \mathrm{~mm}, 5 \mu \mathrm{m})$ and mobile phase comprising $1 \mathrm{mM}$ ammonium acetate buffer: Acetonitrile $(10: 90 \mathrm{v} / \mathrm{v})$ at a flow rate of $1.0 \mathrm{~mL} / \mathrm{min}$, which gave good resolution and acceptable peak parameters. (Figure 2). The detection was carried out at $290 \mathrm{~nm}$. The retention time was found to be $6.15 \pm 0.03 \mathrm{~min}$. The method was validated as per ICH guidelines (ICH 2005).

\section{Preparation of $1 \mathrm{mM}$ Ammonium Acetate Buffer and Mobile Phase (Indian} Pharmacopoeia 2007)

Ammonium acetate buffer $(1 \mathrm{mM})$ was prepared by dissolving $7.71 \mathrm{mg}$ of ammonium acetate in $80 \mathrm{~mL}$ of HPLC grade water, $0.05 \mathrm{~mL}$ acetic acid was added and volume made up to $100 \mathrm{~mL}$ with HPLC grade water. Mobile phase was prepared by mixing acetonitrile and $1 \mathrm{mM}$ ammonium acetate buffer in the ratio of $90: 10 \mathrm{v} / \mathrm{v}$. It was then filtered through $0.45 \mu \mathrm{m}$ membrane filter paper using filtration assembly and then sonicated on ultrasonic water bath for $15 \mathrm{~min}$.

\section{Preparation of Standard Stock Solution}

Standard stock solution of fenofibrate was prepared by dissolving $10 \mathrm{mg}$ of fenofibrate in $10 \mathrm{~mL}$ of acetonitrile to get concentration of $1,000 \mu \mathrm{g} / \mathrm{mL}(A)$. From the standard stock solution, working standard solution was prepared containing $100 \mu \mathrm{g} / \mathrm{mL}$ of fenofibrate in acetonitrile. From this further dilution was made in acetonitrile to get final $10 \mu \mathrm{g} / \mathrm{mL}$ concentration. 


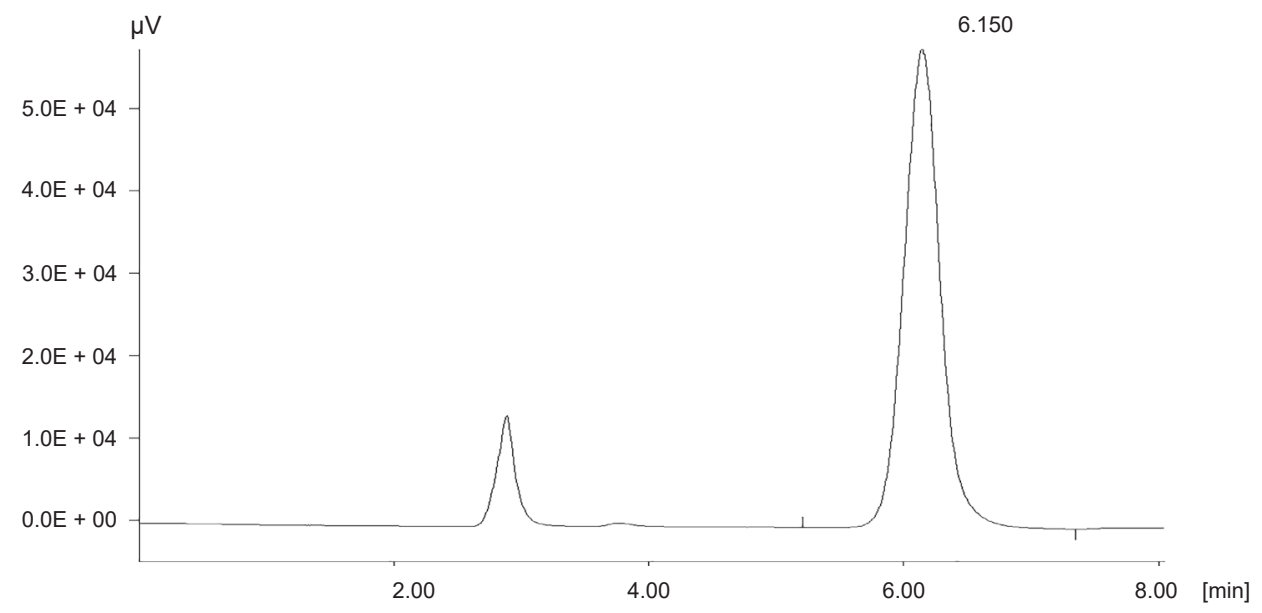

Figure 2: Representative chromatograph of fenofibrate $(10 \mu \mathrm{g} / \mathrm{mL})(R T 6.15 \pm 0.03 \mathrm{~min})$. The peak at 2.85 is solvent peak.

\section{Preparation of Sample Solution}

Twenty tablets each containing $80 \mathrm{mg}$ of fenofibrate were weighed and crushed to powder. Powder equivalent to $10 \mathrm{mg}$ of fenofibrate was transferred to $10 \mathrm{~mL}$ volumetric flask and was diluted with acetonitrile, sonicated for $10 \mathrm{~min}$ and volume made to $10 \mathrm{~mL}$ with acetonitrile. Solution was filtered and further dilutions were made with acetonitrile to get the final concentration of $10 \mu \mathrm{g} / \mathrm{mL}$ of fenofibrate.

\section{Determination of $\lambda_{\max }$ of Fenofibrate by UV Spectroscopy}

Fenofibrate $10 \mathrm{mg}$ was accurately weighed and dissolved in $10 \mathrm{~mL}$ of methanol to obtain a concentration of $1 \mathrm{mg} / \mathrm{mL}$. The solution was then suitably diluted with distilled water to get a final concentration of $10 \mu \mathrm{g} / \mathrm{mL}$. UV spectrum was recorded on Jasco double beam UV-Vis spectrophotometer (Model V550) over wavelength range $200 \mathrm{~nm}-400 \mathrm{~nm}$. The $\lambda_{\max }$ was found to be $290 \mathrm{~nm}$ (Figure 3).

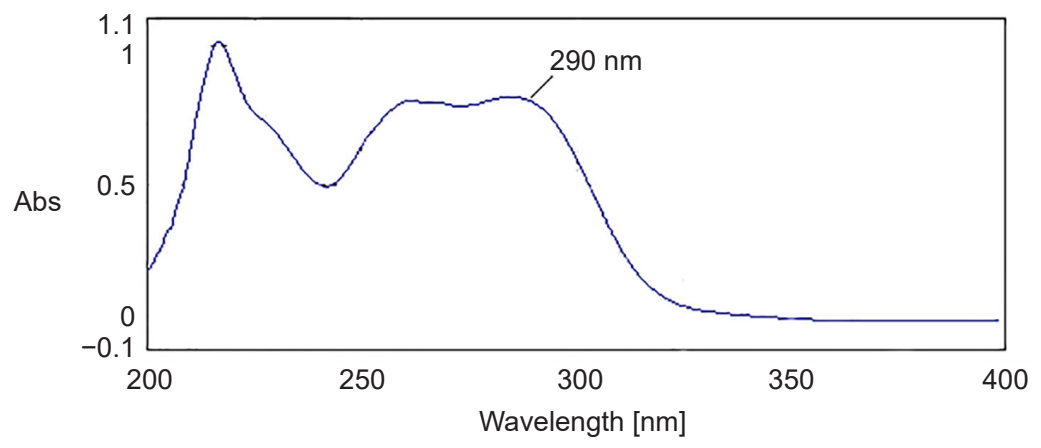

Figure 3: UV spectra of fenofibrate 


\section{RESULTS}

Validation of Analytical Method (ICH 2005)

\section{Linearity (ICH 2005)}

From the standard stock solution $(1,000 \mu \mathrm{g} / \mathrm{mL})$, solution was prepared containing $100 \mu \mathrm{g} / \mathrm{mL}$ of fenofibrate with acetonitrile. This solution was further used to prepare range of solution containing six different concentrations. The linearity (relationship between peak area and concentration) was determined by analysing five replicates over the concentration range of $5-30 \mu \mathrm{g} / \mathrm{mL}$. The equation of calibration curve was found to be $y=126255 x-35592$ with $r^{2}=0.997$. The results obtained are shown in Table 2 .

Table 2: Linearity of fenofibrate.

\begin{tabular}{|c|c|c|c|c|c|c|}
\hline \multirow{2}{*}{ Replicates } & \multicolumn{6}{|c|}{ Concentrations of fenofibrate } \\
\hline & $5 \mu \mathrm{g} / \mathrm{mL}$ & $10 \mu \mathrm{g} / \mathrm{mL}$ & $15 \mu \mathrm{g} / \mathrm{mL}$ & $20 \mu \mathrm{g} / \mathrm{mL}$ & $25 \mu \mathrm{g} / \mathrm{mL}$ & $30 \mu \mathrm{g} / \mathrm{mL}$ \\
\hline & \multicolumn{6}{|c|}{ Peak area } \\
\hline 1 & 571367.8 & 1196436.0 & 1979121.8 & 2454209.0 & 3072397.0 & 3769700.0 \\
\hline 2 & 560655.5 & 1162149.0 & 1928560.0 & 2391534.0 & 2961390.0 & 3729161.0 \\
\hline 3 & 586211.9 & 1160268.0 & 1990811.0 & 2380938.0 & 2942197.0 & 3643038.0 \\
\hline 4 & 579245.0 & 115131.0 & 2003144.6 & 2454143.8 & 3022452.0 & 3797519.0 \\
\hline 5 & 580241.2 & 1190735.0 & 1964916.0 & 2441704.0 & 3009879.0 & 3654640.0 \\
\hline Mean & 575544.3 & 1180943.0 & 1973310.6 & 2424505.6 & 3001663.0 & 3718811.0 \\
\hline SD & 9857.4 & 18151.5 & 28736.8 & 35502.7 & 51626.7 & 68468.1 \\
\hline RSD (\%) & 1.712 & 1.537 & 1.456 & 1.46 & 1.71 & 1.84 \\
\hline
\end{tabular}

\section{Limit of Detection and Limit of Quantification (ICH 2005)}

Limit of detection (LOD) and limit of quantification (LOQ) are calculated from the formula:

$$
\mathrm{LOD}=3.3 \sigma / \mathrm{S} \text { and } \mathrm{LOQ}=10 \mathrm{\sigma} / \mathrm{S}
$$

Where,

$\sigma=$ standard deviation of $y$ intercept

$\mathrm{S}=$ slope of the calibration curve

The LOD and LOQ were found to be $0.14 \mu \mathrm{g} / \mathrm{mL}$ and $0.45 \mu \mathrm{g} / \mathrm{mL}$, respectively.

\section{Precision (ICH 2005)}

The precision of the method was demonstrated by intra-day and inter-day variation studies. In the intra-day studies, $3 \times 3$ replicates of fenofibrate $10 \mu \mathrm{g} / \mathrm{mL}, 20 \mu \mathrm{g} / \mathrm{mL}$ and $25 \mu \mathrm{g} / \mathrm{mL}$ were analysed in a day and percentage relative standard deviation (RSD) was calculated. 
For the inter-day variation studies, three different concentrations were analysed on three consecutive days and percentage RSD were calculated. The results obtained were found to be within limits (less than $2 \% \mathrm{RSD}$ ). The results obtained for intra-day and inter-day variations are shown in Tables 3 and 4.

Table 3: Inter-day precision of fenofibrate.

\begin{tabular}{lccr}
\hline \multirow{2}{*}{ Replicates } & \multicolumn{3}{c}{ Concentration $(\boldsymbol{\mu g} / \mathrm{mL})$} \\
\cline { 2 - 4 } & $\mathbf{1 0}$ & $\mathbf{2 0}$ & \multicolumn{1}{c}{$\mathbf{2 5}$} \\
\hline 1 & 1165243.5 & 2346354.2 & 3013652.1 \\
2 & 1195324.6 & 2415642.6 & 3025479.2 \\
3 & 1173986.3 & 2339546.0 & 2993146.4 \\
Mean & 1178184.8 & 2367180.9 & 3010759.2 \\
SD & 15473.8 & 42106.9 & 16359.4 \\
RSD (\%) & 1.313 & 1.778 & 0.543 \\
\hline
\end{tabular}

Table 4: Intra-day precision of fenofibrate.

\begin{tabular}{lccc}
\hline \multirow{2}{*}{ Replicates } & \multicolumn{3}{c}{ Concentration $(\boldsymbol{\mu g} / \mathrm{mL})$} \\
\cline { 2 - 4 } & $\mathbf{1 0}$ & $\mathbf{2 0}$ & $\mathbf{2 5}$ \\
\hline 1 & 1175487.3 & 2435976.3 & 2986571.1 \\
2 & 1165897.0 & 2395687.1 & 2965324.9 \\
3 & 1145678.3 & 2401597.8 & 3004213.2 \\
Mean & 1162354.2 & 2411087.1 & 2985369.7 \\
SD & 15217.0 & 21756.4 & 19472.0 \\
RSD (\%) & 1.309 & 0.902 & 0.652 \\
\hline
\end{tabular}

Specificity (ICH 2005)

The specificity of the method was ascertained by peak purity profiling studies. The peak purity values were found to be more than 991 , indicating the no interference of any other peak of degradation product, impurity or matrix.

Assay (ICH 2005)

Tablet formulation analysis was carried out as mentioned under section preparation of sample solution. Procedure was repeated for six times. Sample solution was injected and area was recorded for each drug. Concentration and \% purity was determined from linear equation. The results obtained are shown in Table 5. 
Table 5: Assay of fenofibrate tablets.

\begin{tabular}{lccc}
\hline Replicates & Peak area & Amount recovered $(\mu \mathrm{g} / \mathrm{mL})$ & Recovery $(\%)$ \\
\hline 1 & 1210805 & 9.872 & 98.720 \\
2 & 1207011 & 9.842 & 98.420 \\
3 & 1206077 & 9.834 & 98.350 \\
4 & 1197074 & 9.763 & 97.633 \\
5 & 1183358 & 9.654 & 96.550 \\
6 & 1208848 & 9.856 & 98.565 \\
Mean & 1202196 & 9.804 & 98.039 \\
SD & 10370.11 & 0.082 & 0.821 \\
RSD (\%) & 0.862598 & 0.840 & 0.838 \\
\hline
\end{tabular}

Accuracy (ICH 2005)

To check accuracy of the method, recovery studies were carried by spiking the standard drug to the tablets sample solution, at three different levels around $50 \%, 100 \%$ and $150 \%$. Basic concentration of sample solution chosen was $10 \mu \mathrm{g} / \mathrm{mL}$ of fenofibrate. Percentages of recovery was determined from linearity equation. The results obtained are shown in Table 6.

Table 6: Recovery studies of fenofibrate.

\begin{tabular}{|c|c|c|c|c|c|c|}
\hline Level & Sample & Standard & Area & $\begin{array}{l}\text { Amount } \\
\text { recovered }\end{array}$ & Recovery (\%) & RSD (\%) \\
\hline \multirow{4}{*}{$50 \%$} & 10 & 5 & 1911099 & 15.41 & 102.79 & 1.51 \\
\hline & & & 1878130 & 15.15 & 101.05 & \\
\hline & & & 1853378 & 14.96 & 99.74 & \\
\hline & Mean & & 1880869 & 15.17 & 101.19 & \\
\hline \multirow{4}{*}{$100 \%$} & 10 & 10 & 2460681 & 19.77 & 98.85 & 0.20 \\
\hline & & & 2451241 & 19.69 & 98.48 & \\
\hline & & & 2453196 & 19.71 & 98.56 & \\
\hline & Mean & & 2455039 & 19.72 & 98.63 & \\
\hline \multirow{4}{*}{$150 \%$} & 10 & 15 & 3066535 & 24.57 & 98.28 & 1.44 \\
\hline & & & 3096392 & 24.80 & 99.22 & \\
\hline & & & 3156123 & 25.27 & 101.11 & \\
\hline & Mean & & 3106350 & 24.88 & 99.54 & \\
\hline
\end{tabular}


Robustness (ICH 2005)

Robustness of the method was determined by carrying out the analysis under conditions during which detection wavelength, flow rate were altered and the effect on the area were noted. The results obtained are shown in Table 7.

Table 7: Robustness study.

\begin{tabular}{lcccccc}
\hline & \multicolumn{3}{c}{ Detection wavelength $\mathbf{\pm 2} \mathbf{~ n m}$} & \multicolumn{3}{c}{ Flow rate $\pm \mathbf{0 . 0 5} \mathbf{~} \mathbf{L} / \mathbf{m i n}$} \\
\hline Fenofibrate & 288 & 290 & 292 & 0.95 & 1.00 & 1.05 \\
RSD (\%) values & 0.53 & 0.96 & 1.26 & 0.78 & 0.96 & 1.33 \\
\hline
\end{tabular}

\section{DISCUSSION}

The developed, method was found to be simple, sensitive, accurate and precise for assay of tablets of fenofibrate prepared using crystallo-co-agglomerates of the drug. Validation of the method was performed for precision, accuracy, linearity, robustness, specificity and sensitivity to conform to the $\mathrm{ICH}$ guidelines for validation of an analytical method. One paper is available in literature for RP-HPLC method (Sahoo, Sahu and Patro 2014). In work the retention time was found to be 19.26 min while in present work is was found to be 6.15 , thus, the present method is time saving. The summary of all validation parameters is given in Table 8.

Table 8: Summary of validation study by HPLC method.

\begin{tabular}{clc}
\hline No. & Validation parameter & Results \\
\hline 1 & Linearity & $\mathrm{y}=126255 \mathrm{x}-35592$ \\
$r^{2}=0.9971$ & $5-30 \mu \mathrm{g} / \mathrm{mL}$ \\
2 & Range & $\mathrm{RSD}(\%)$ \\
3 & Precision & 0.95 \\
& Intra-day precision & 1.21 \\
& Inter-day precision & $2.62 \mu \mathrm{g} / \mathrm{mL}$ \\
4 & Limit of detection & $7.96 \mu \mathrm{gg} / \mathrm{mL}$ \\
5 & Limit of quantitation & 98.03 \\
6 & Assay & 99.79 \\
7 & Accuracy & Robust \\
8 & Robustness & Specific \\
9 & Specificity &
\end{tabular}

Malay J Pharm Sci, Vol. 19, No. 1 (2021): 19-28 


\section{CONCLUSION}

The developed RP-HPLC method was found to be simple, precise, accurate, linear, robust, specific and sensitive, and can be successfully used for estimation of fenofibrate in tablet dosage form in routine analysis.

\section{REFERENCES}

CHOUDHARI, V. P. \& NIKALJE, A. P. (2010) Simultaneous estimation of atorvastatin, ezetimibe and fenofibrate in pharmaceutical formulation by RP-LC-PDA, Pharmaceutica Analytica Acta, 1(1): 111. https://doi.org/10.4172/2153-2435.1000111

DEEPAN, T., AMBETHKAR, K. P., LAKSHMI, G. V. \& DHANARAJU, M. D. (2011) Analytical method development and validation of RP-HPLC for estimation of atorvastatin calcium and fenofibrate in bulk drug and tablet dosage forms, European Journal of Applied Sciences, 3(2): 35-39.

DONGARE, T. D., BHALEKAR, M. R. \& GANDHI S. V. (2017) Formulation optimization and pharmacokinetics of tinidazole crystallo-co-agglomerates. MOJ Bioequivalance \& Bioavailability, 3(5): 47-54. https://doi.org/10.15406/mojbb.2017.03.00047

GUPTA, K. R., ASKARKAR, S. S., RATHOD P. R. \& WADODKAR, S. G. (2010) Validated spectrophotometric determination of fenofibrate in formulation, Der Pharmacia Sinica, 1: 173-178.

INDIAN PHARMACOPOEIA (2007) The Indian Pharmacopoeia Commission Ghaziabad. pp. 1-242 (Ghaziabad, India: Indian Pharmacopoeia Commission).

INTERNATIONAL CONFERENCE ON HARMONIZATION (ICH). (2005) Q2 (R1), Validation of analytical procedures: Text and methodology, ICH Harmonised Tripartite Guideline. International Conference on Harmonisation of Technical Requirements for Registration of Pharmaceuticals for Human Use, Chicago, USA, 2005.

KADAM, S., MAHADIK, K. \& PARADKAR, A. (1997) A process for making agglomerates for use as or in a drug delivery system, Indian patent 183036.

MANISH KUMAR, T., SRIKANTH, G., PAMULAPARTHYA, V., RAO, J. V. \& RAO, K. R. S. (2011) Development and validation of HPLC-UV method for the estimation of fenofibrate in human plasma, Journal of Pharmacy Research, 4(10): 3735-3737.

PATIL, P., SRIKANTH, K., PATI, N. \& GIRI PRASAD, B. S. (2011) Spherical agglomerationdirect tableting technique, International Research Journal of Pharmacy, 2 (11): 30-35.

RAO, K. S., KESHAR, N. K., JENA, N., RAO, M. E. B. \& PATNAIK, A. K. (2013) Stability indicating liquid chromatograpic method for the determination of fenofibrate and its application to kinetic studies, International Journal of Pharmaceutical Sciences and Nanotechnology, 5(4): 1866-1874. https://doi.org/10.37285/ijpsn.2012.5.4.6 
SAHOO, D., SAHU P. \& PATRO, C. S. (2014) New validated isocratic RP-HPLC method for assay of fenofibrate, International Journal of Pharmacy And Pharmaceutical Sciences, 6(2): 169-172.

SALAMA, FATHY M. M., NASSAR, MOHAMED W. I., SHARAF EL-DIN, MOHIE M. K., ATTIA, KHALID A. M. \& KADDAH M. Y. (2011) Determination of fenofibrate and the degradation product using simultaneous UV-derivative spectrometric method and HPLC, American Journal of Analytical Chemistry, 2: 332-343. https://doi.org/10.4236/ajac.2011.23041

SURESH KUMAR, G. V. \& RAJENDRA PRASAD, Y. (2010) Development and validation of reversed-phase HPLC method for simultaneous estimation of rosuvastatin and fenofibrate in tablet dosage form, International Journal of Pharmtech Research, 2(3): 2016-2021.

THRIVENI, J., RAMBABU, R., RAO, J. V. \& VIDYADHARA S. (2013) Development and validation of RP-HPLC method for simultaneous estimation of rosuvastatin calcium and fenofibrate in bulk and pharmaceutical dosage forms, International Journal of Research in Pharmacy and Chemistry, 3(2): 208-212.

ZAMAN, M. T., KHAN, S. A., ARORA, A. \& AHMAD O. (2009) Method development and validation of fenofibrate by HPLC using human plasma, The Electronic Journal of Biomedicine, 3: 41-54. 